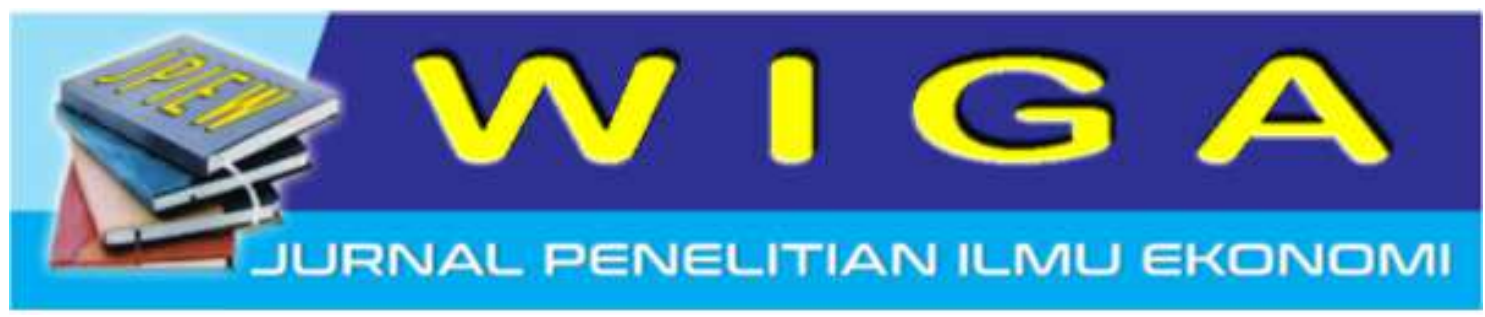

\title{
PENGARUH KUALITAS PRODUK TERHADAP TINGKAT KEPUASAN NASABAH
}

\author{
Muhammad Ridwan Basalamah
}

Fakultas Ekonomi, Universitas Islam Malang

Email: ridwanbasalamah19@gmail.com

\begin{abstract}
ABSTRAK
Bank Rakyat Indonesia merupakan Bank Pemerintah Pertama di Indonesia. Memiliki visi yaitu menjadi bank komersial terkemuka yang selalu mengutamakan kepuasan nasabah. Berdasarkan visi tersebut BRI Cabang Kota Makassar selalu melakukan evaluasi dari tahun ke tahun dalam hal penciptaan kepuasan nasabah. BRI Cabang Kota Makassar sadar betul bahwa kualitas produk memiliki peran penting dalam penciptaan kepuasan nasabah. Nasabah yang semakin kritis terhadap kualitas produk yang diperoleh, membuat BRI Cabang Kota Makassar harus dapat melaksanakan kegiatan operasional sebaik mungkin untuk memberikan produk terbaik kepada nasabahnya penelitian ini mencakup dua hal yaitu kualitas produk mempengaruhi kepuasan nasabah atau kualitas produk tidak mempengaruhi kepuasan nasabah.

Penelitian ini dilakukan pada unit kerja operasional Bank BRI di Sulawesi Selatan yang terdiri dari 10 buah kantor cabang untuk 10 kabupaten dan Kota, antara lain Kantor Cabang BRI Makassar, Maros, Pangkep, Sidrap, Sengkang, Palopo, Sungguminasa, Takalar, Jeneponto, dan Bulukumba, Populasi dalam penelitian ini adalah jumlah nasabah yang menabung pada rekening tabungan Britama BRI pada Kantor Cabang BRI di Sulawesi Selatan, karena jenis tabungan ini memiliki fitur dan karakteristik yang relatif sama dan merupakan produk tabungan Bank BRI yang diunggulkan.

Hasil penelitian menunjukkan bahwa kualitas produk terhadap kepuasan nasabah terdapat pengaruh secara positif dan signifikan, yang berarti bahwa semakin tinggi persepsi nasabah terhadap kualitas produk tabungan Britama, maka nasabah semakin merasa puas. Hal ini berarti bahwa semakin baik kualitas produk tabungan yang diberikan oleh Bank BRI di Sulawesi Selatan, maka nasabah semakin merasa puas terhadap produk Bank BRI di Sulawesi Selatan
\end{abstract}

Kata Kunci : Kualitas Produk, Kepuasan Nasabah

\section{PENDAHULUAN}

Bank merupakan suatu perusahaan yang bergerak dalam bidang berkompetisi menarik nasabah dengan memberikan produk perbankan yang beraneka ragam dan berkualitas. Untuk memenangkan persaingan setiap organisasi atau penyedia jasa perbankan harus memperhatikan kebutuhan dan keinginan konsumen atau para nasabah, serta berusaha memenuhi harapan mereka, sehingga mampu memberikan kepuasan kepada nasabahnya.

Bank Rakyat Indonesia merupakan Bank Pemerintah Pertama di Indonesia. Memiliki visi yaitu menjadi bank komersial terkemuka yang selalu mengutamakan kepuasan nasabah. Berdasarkan visi tersebut BRI Cabang Kota Makassar selalu melakukan evaluasi dari tahun ke tahun dalam hal penciptaan kepuasan nasabah. BRI Cabang Kota Makassar sadar betul bahwa kualitas 
produk memiliki peran penting dalam penciptaan kepuasan nasabah. Nasabah yang semakin kritis terhadap kualitas produk yang diperoleh, membuat BRI Cabang Kota Makassar harus dapat melaksanakan kegiatan operasional sebaik mungkin untuk memberikan produk terbaik kepada nasabahnya.

$$
\text { Selanjutnya yang bisa }
$$

mendongkrak pangsa pasar suatu perbankan dan juga perusahaan lain yang bergerak di bidang jasa adalah kualitas produk. Adrian Payne mendefenisikan kualitas produk adalah suatu bentuk dengan nilai kepuasan yang kompleks. Nasabah membeli jasa perbankan untuk menyelesaikan masalah dan nasabah memberikan nilai dalam proporsi terhadap kemampuan layanan untuk melakukan hal tersebut. Nilai yang diberikan berhubungan dengan benefit atau keuntungan yang akan diterimanya. Kualitas produk perbankan didapatkan dengan cara menemukan keseluruhan harapan nasabah, meningkatkan nilai produk dalam rangka memenuhi harapan nasabah tersebut.

Menurut Tjiptono, (2004) kepuasan pelanggan dapat dinyatakan sebagai salah satu atau suatu ratio atau perbandingan dengan kualitas barang atau kualitas jasa yang didapat atau yang dirasakan dengan keinginan, kebutuhan, dan harapan yang diinginkan atau yang diekspektasikan dari masing-masing individu atau pelanggan yang telah terpenuhi atau tercapai harapannya. Suprapto (1997) menambahkan bahwa tingkat kepuasan pelanggan sangat bergantung pada mutu suatu produk. Tingkat kualitas yang tinggi akan menghasilkan kepuasan pelanggan yang tinggi. Memang kepuasan pelanggan secara individu sangat sulit untuk dicapai karena keanekaragaman keinginan pelanggan, hal ini memerlukan diadakannya pendekatan untuk mendapatkan solusi optimal. Dengan menjaga kepuasan pelanggan akan dapat meningkatkan kelangsungan hubungan dengan pelanggan lama dan terus membina pelanggan baru. Dengan konsep kepuasan pelanggan, kita akan mempunyai pengaruh yang lebih besar dari bagian pasar.

\section{KAJIAN PUSTAKA}

\subsection{Kualitas Produk}

Kualitas adalah suatu tujuan yang sukar dipahami sebab harapan nasabah selalu berubah. Setiap suatu standar yang baik ditentukan, maka konsumen akan menuntut lagi agar diperoleh standar yang lebih baik, sehingga selalu dituntut adanya peningkatan standar. Sehingga kualitas didefinisikan sebagai sebuah proses bukan merupakan hasil akhir. Tjiptono (2004) mendefinisikan kualitas produk yaitu (a) performance to the standard expected by the customer, (b) meeting the Customer's need the first time and every time, (c) providing our customer with products and service that consistenly meet their need and expectations, (d) the meeting of excellence, (e) Doing the right the first time, always striving for improvement and always satisfaying the customer.

Kualitas produk itu sendiri cenderung memiliki makna berbeda bagi setiap orang dan tergantung pada konteksnya. Beberapa pakar dan organisasi mencoba mendefinisikan kualitas berdasarkan sudut pandangnya masingmasing. Beberapa diantaranya paling populer adalah dikembangkan oleh tiga pakar kualitas produk yaitu Yamit, Crosby, Juran. Untuk produk perbankan, sebenarnya yang dibeli nasabah bukan semata-mata produk dalam wujud fisiknya, melainkan manfaat pemenuhan kebutuhan dan keinginan nasabah yang ditawarkan melalui produk perbankan. Yamit (2004) mendefinisikan kualitas produk perbankan adalah apapun yang menjadi kebutuhan atau keinginan nasabah. Bank akan berusaha menginventarisasi kebutuhan dan keinginan nasabah kemudian mengemasnya dalam bentuk produk perbankan yang berbeda dengan produk perbankan lainnya.

Enam dimensi kualitas produk perbankan yang digunakan dalam 
penelitian ini yaitu performance, range and type of features, maintainability and serviceability, sensory characteristics, reliability and durability and ethical profile and image. Yamit (2004) menyatakan produk perbankan dikatakan berkualitas jika memenuhi delapan indikator yaitu performance, features, reliability,serviceability, conformance, durability, estetica, and perceived. Namun dalam penelitian ini akan direduksi menjadi enam indikator dengan mengacu pada enam dimensi kualitas produk yang dikemukakan oleh Yamit yaitu performance, range and type of features, reliability and durability, maintainability and serviceability, sensory characteristics, ethical profile and image. Performance yaitu kualitas produk menggambarkan keadaan yang sebenarnya misalnya ketepatan transaksi, range and type of features yaitu fungsi utama dari produk perbankan yang ditawarkan. Nasabah seringkali tertarik dengan kemampuan dan keistemewaan produk perbankan yang ditawarkan, misalnya kemampuan transaksi luar negeri, reliability and durability yaitu kehandalan produk perbankan yang ditawarkan dan berapa lama produk perbankan tersebut dapat dinikmati, misalnya pelayanan segera dan tepat, maintainability and serviceability yaitu kemudahan dalam penggunaan dan jasa purna jual yang memadai, sensory characteristics yaitu penampilan, corak jasa, daya tarik dan beberapa faktor lain yang menjadi aspek kualitas produk perbankan, misalnya fasilitas yang lengkap, dan ethical profile and image yaitu kesan nasabah terhadap produk perbankan yang ditawarkan, misalnya advertensi yang wajar. Pertimbangan pemilihan keenam indikator tersebut karena keenam indikator telah cukup lengkap mengukur kualitas produk perbankan. Keenam dimensi tersebut memberikan gambaran terhadap sikap atau penilaian nasabah dengan cara evaluasi secara menyeluruh terhadap suatu produk perbankan.

Figure 1 : Kualitas Produk Hubungan antara Bank Dengan Nasabah

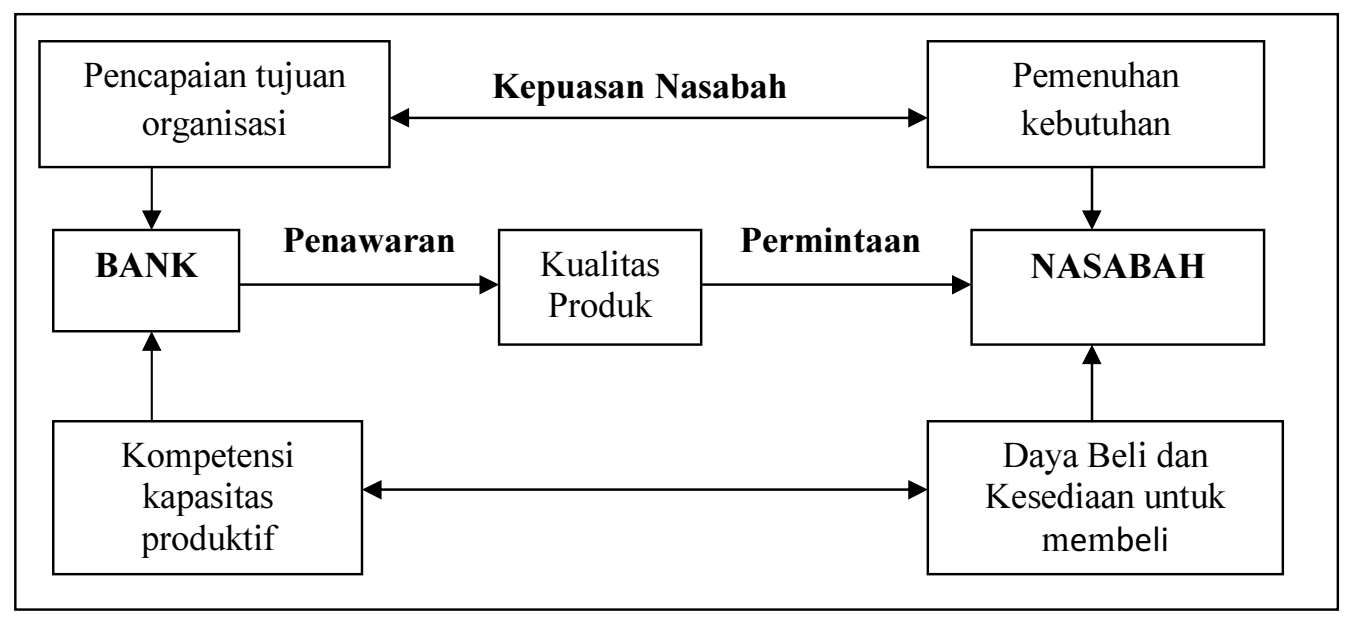

Sumber : Tjiptono (2004)

\subsection{Kepuasan Nasabah}

Kotler (2009) menyatakan kepuasan adalah perasaan senang atau kecewa seseorang yang berasal dari perbandingan antara kesannya terhadap kinerja (atau hasil) suatu dan harapanharapannya. Jadi tingkat kepuasan adalah fungsi dari perbedaan antara kinerja yang dirasakan dengan harapan. Kemudian kepuasan konsumen menurut Oliver (1997) mengatakan bahwa kepuasan adalah tanggapan pemenuhan konsumen, merupakan keputusan bahwa citra produk atau jasa itu sendiri menyediakan tingkat menyenangkan atas pemenuhan konsumsi 
bersangkutan, termasuk tingkat pemenuhan yang rendah atau yang tinggi.

Suatu kesalahan yang umum dilakukan didalam pengukuran kepuasan nasabah adalah dengan mengasumsikan bahwa kualitas aktual sama dengan kualitas yang diharapkan. Sementara itu dalam pengukuran terhadap kepuasan nasabah, Fornell et al., (1996) menggunakan tiga item dalam mengukur kepuasan nasabah yaitu : (1) overal satisfaction adalah hasil evaluasi dan pengalaman konsumsi sekarang yang berasal dari kebiasaan, kendala dan standarisasi pelayanan; (2) confirmation of expevtation adalah tingkat kesesuaian antara kinerja dan harapan nasabah; (3) comparison of ideal adalah kinerja produk dibandingkan dengan kondisi idel menurut persepsi nasabah. Sebenarnya ketiga item tersebut merupakan penjabaran dari persepsi dan harapan nasabah dalam menilai kepuasan nasabah secara menyeluruh.

\section{KERANGKA KONSEPTUAL DAN HIPOTESIS}

\subsection{Kerangka konseptual}

Kerangka konseptual ini menjelaskan tentang hubungan antar variabel penelitian. Hubungan antar variabel penelitian ini didasarkan pada teori kualitas produk dan teori kepuasan, serta hasil-hasil penelitian yang berkaitan dengan hubungan antara kualitas produk, terhadap kepuasan nasabah. Berdasarkan pada hubungan antar variabel baik berdasarkan teori dan penelitian terdahulu tersebut maka disusun kerangka konseptual penelitian.

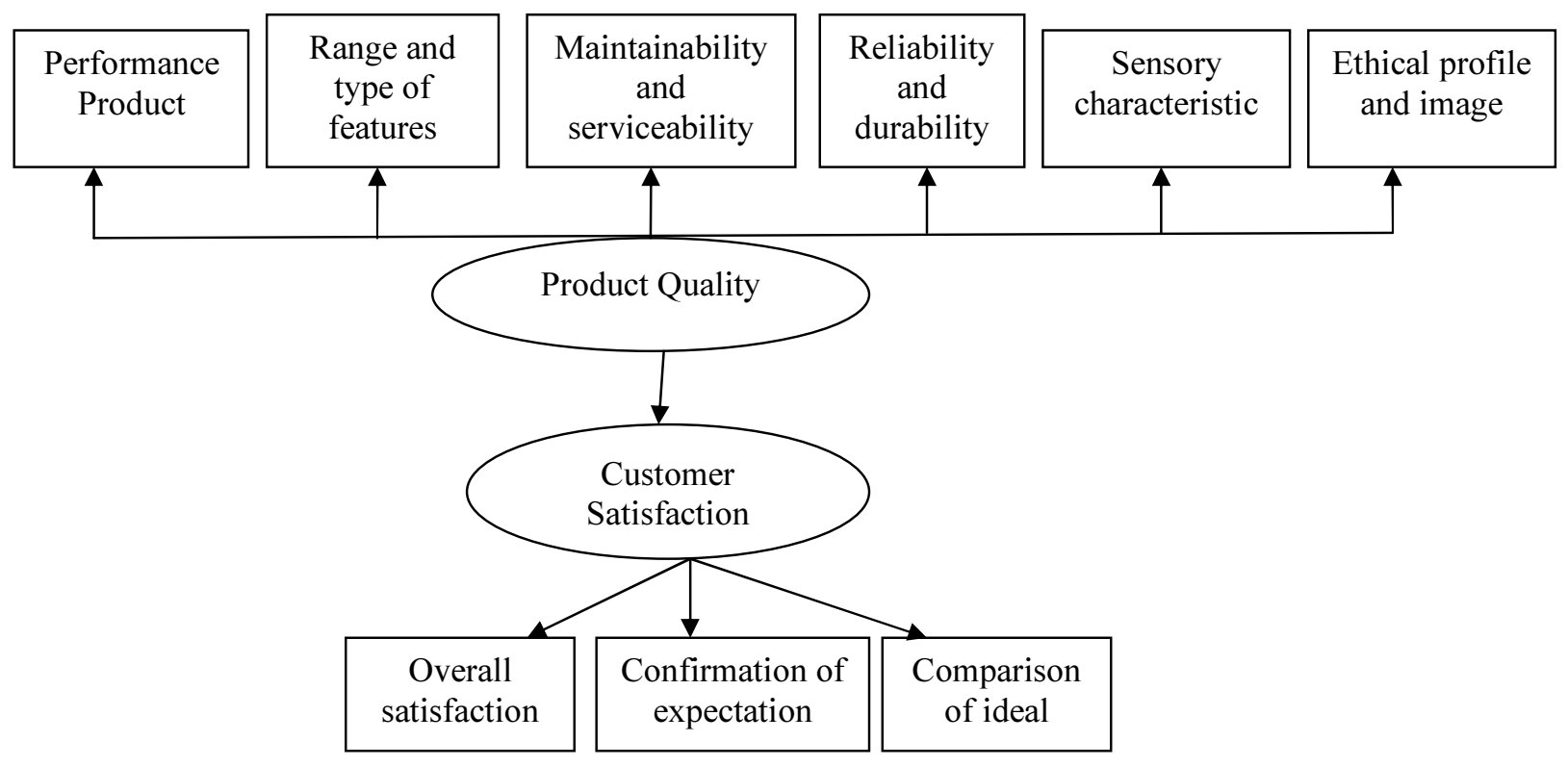

\subsection{Hipotesis}

Nasabah adalah penentu atau penilai tentang kualitas suatu produk. Banyak ukuran yang bisa dipakai nasabah dalam menentukan kualitas suatu produk perbankan. Namun tujuan akhir yang

\section{Figure 2. Research Framework}

dicapai adalah sama yaitu mampu memberikan rasa puas kepada nasabah. Semakin puas seorang nasabah dalam mengkonsumsi suatu produk perbankan maka dapat dikatakan semakin berkualitas produk perbankan tersebut. Puas atau tidak 
puasnya seorang nasabah ditentukan oleh kesesuaian harapan nasabah dengan persepsi nasabah pada kinerja aktual produk.

Holm (2000), Bei dan Chain (2001) menyatakan bahwa kualitas produk mepengaruhi kepuasan nasabah. Nasabah mengkonsumsi produk perbankan memberikan nilai dalam proporsi terhadap kemampuan produk dalam memenuhi kebutuhannya. Nilai yang diberikan nasabah berhubungan dengan benefit atau keuntungan yang akan diterimanya.

Berdasarkan penjelasan diatas, maka hipotesis dalam penelitian ini mencakup dua hal yaitu kualitas produk mempengaruhi kepuasan nasabah atau kualitas produk tidak mempengaruhi kepuasan nasabah. Berikut ini adalah hipotesis statistik.

$\mathrm{H} 0=$ kualitas produk tidak mempengaruhi kepuasan nasabah

$\mathrm{H1}=$ kualitas produk mempengaruhi kepuasan nasabah

Selanjutnya untuk kriteria pengujian hipotesis merujuk pada perbandingan antara $t_{\text {hitung }}$ degan $t_{\text {tabel }} \cdot$ jika $\mathrm{t}_{\text {hitung }}<\mathrm{t}_{\text {tabel }}$ maka h0 diterima, sebaliknya jika $t_{\text {hitung }}>t_{\text {tabel }}$ maka $h 1$ diterima. $t_{\text {tabel }}$ dalam penelitian ini sebesar 0,67 dengan jumlah sampel 200.

\section{DEFINISI OPERASIONAL}

Kualitas produk adalah kondisi dimana nasabah merasa puas terhadap kesesuaian antara harapan dengan kondisi aktual produk Bank BRI dengan indikator (Yamit, 2004) yang meliputi, performance product, range and type of features, maintainability and serviceability, sensory characteristics, reliability and durability and ethical profile and image.

Kepuasan nasabah adalah kondisi yang menjelaskan tentang respon nasabah terhadap evaluasi ketidaksesuaian yang dirasakan antara harapan sebelumnya dengan kinerja aktual yang dirasakan setelah pemakaian, atau perbandingan antara persepsi dengan harapan nasabah terhadap layanan Bank BRI (Fornell, et al.,
1996) yang meiputi overall satisfaction, confiration of expectation, and comparison of ideal.

\section{METODOLOGI}

Lokasi penelitian yaitu semua unit kerja operasional Bank BRI di Sulawesi Selatan yang terdiri dari 20 buah kantor cabang untuk 20 kabupaten dan Kota, antara lain Kantor Cabang BRI Makassar, Maros, Pangkep, Sidrap, Sengkang, Palopo, Sungguminasa, Takalar, Jeneponto, dan Bulukumba,. Penelitian ini bertujuan untuk mengetahui pengaruh antar variabel penelitian (kualitas produk serta kepuasan nasabah), sehingga penelitian ini masuk kategori penelitian eksplanatori yaitu suatu penelitian untuk mencari dan menjelaskan pengaruh antar variabel melalui pengujian hipotesis, (Sekaran, 2006). Populasi dalam penelitian ini adalah jumlah nasabah yang menabung pada rekening tabungan Britama BRI pada Kantor Cabang BRI di Sulawesi Selatan, karena jenis tabungan ini memiliki fitur dan karakteristik yang relatif sama dan merupakan produk tabungan Bank BRI yang diunggulkan.

\section{HASIL DAN TEMUAN}

Tabel 1 : Skor Rata-Rata Variabel Kualitas Produk Bank BRI

\begin{tabular}{|c|l|c|}
\hline No & \multicolumn{1}{|c|}{ Indikator } & $\begin{array}{c}\text { Skor } \\
\text { Rata- } \\
\text { Rata }\end{array}$ \\
\hline $\mathbf{1}$ & $\begin{array}{l}\text { Performance/Proses } \\
\text { layanan tabungan sangat } \\
\text { mudah }\end{array}$ & $\mathbf{3 , 9 9}$ \\
\hline $\mathbf{2}$ & $\begin{array}{l}\text { Range and type of } \\
\text { features/ terdapat fasilitas } \\
\text { ATM, SMS Banking, }\end{array}$ & $\mathbf{4 , 0 0}$ \\
$\begin{array}{l}\text { Internet Banking, Phone } \\
\text { Banking, Hadiah Undian } \\
\text { pada tabungan BRI }\end{array}$ & $\begin{array}{l}\text { Maintainability and } \\
\text { Serviceability/ 4,10 } \\
\text { Penyetoran dan } \\
\text { Penarikan tabungan } \\
\text { online di semua kantor } \\
\text { BRI }\end{array}$ \\
\hline
\end{tabular}




\begin{tabular}{|c|l|c|}
\hline $\mathbf{4}$ & $\begin{array}{l}\text { Sensory characteristics/ } \\
\text { Kartu ATM BRI mudah } \\
\text { digunakan pada mesin }\end{array}$ & $\mathbf{3 , 9 2}$ \\
ATM bank lain & \\
\hline $\mathbf{5}$ & $\begin{array}{l}\text { Reliability and } \\
\text { Durability/ perhitungan } \\
\text { bunga tabungan benar } \\
\text { dan tepat waktu setiap } \\
\text { bulannya }\end{array}$ & $\mathbf{3 , 8 6}$ \\
\hline $\mathbf{6}$ & $\begin{array}{l}\text { Ethical profile and } \\
\text { Image/ Produk tabungan }\end{array}$ & $\mathbf{3 , 9 4}$ \\
$\begin{array}{l}\text { BRI memberikan rasa } \\
\text { percaya diri bagi nasabah }\end{array}$ & \\
\hline & Rata-Rata & $\mathbf{3 , 9 7}$ \\
\hline
\end{tabular}

Tabel 1 diatas menunjukkan bahwa indikator perhitungan bunga tabungan benar dan tepat waktu setiap bulannya masih berada dibawah dengan nilai skor indikator sebesar $(3,86)$, sehingga Bank BRI masih perlu meningkatkan metode perhitungan bunga yaitu bunga harian dengan saldo yang ditentukan oleh pihak bank, kalau ketepatan dan kebenaran sudah dapat diyakini dan diterima oleh para nasabah karena dihitung dengan by system setiap tanggal 20 tabungan Britama setiap bulan. Sedangkan indikator paling tinggi skornya menurut persepsi nasabah adalah penyetoran dan penarikan tabungan online di semua unit kerja kantor Bank BRI sebesar 4,10, karena semua unit kerja bank BRI terkoneksi secara terintegrasi/BRI Network Integration System (Brinets).

Tabel 2 : Skor Rata-Rata Variabel Kepuasan Nasabah Bank BRI

\begin{tabular}{|c|l|c|}
\hline No & \multicolumn{1}{|c|}{ Indikator } & $\begin{array}{c}\text { Skor } \\
\text { rata- } \\
\text { Rata }\end{array}$ \\
\hline $\mathbf{1}$ & $\begin{array}{l}\text { Bank BRI mampu } \\
\text { memberikan layanan } \\
\text { tabungan yang terbaik } \\
\text { dan menyeluruh sesuai } \\
\text { standar }\end{array}$ & $\mathbf{3 , 8 8}$ \\
\hline $\mathbf{2}$ & $\begin{array}{l}\text { Kemampuan Bank BRI } \\
\text { memberikan layanan } \\
\text { tabungan sesuai } \\
\text { harapan para nasabah }\end{array}$ & $\mathbf{3 , 9 4}$ \\
\hline $\mathbf{3}$ & $\begin{array}{l}\text { Kemampuan Bank BRI } \\
\text { memberikan layanan }\end{array}$ & $\mathbf{3 , 8 9}$ \\
\hline
\end{tabular}

\begin{tabular}{|l|l|c|}
\hline & $\begin{array}{l}\text { tabungan sesuai dengan } \\
\text { persepsi nasabah }\end{array}$ & \\
\hline & Rata-rata & $\mathbf{3 , 9 0}$ \\
\hline
\end{tabular}

Tabel 2 diatas, ketiga indikator variabel kepuasan nasabah secara umum menggambarkan rata-rata nasabah memberikan persepsi yang baik sebesar 3,90, ini memberikan indikasi bahwa nasabah selama melakukan transaksi terpenuhi keinginannya. Namun yang lebih penting untuk Bank BRI adalah keinginan nasabah akan selalu terwujud dimasa yang akan datang untuk selalu bertransaksi.

Hasil analisis regresi menghasilkan besarnya pengaruh variabel kualitas produk terhadap kepuasan nasabah sebesar 0,218 atau $21,8 \%$ dengan nilai probabilitas $(\mathrm{P})=0,013<0,05$. Artinya terdapat pengaruh secara positif dan signifikan, yang berarti bahwa semakin tinggi persepsi nasabah terhadap kualitas produk tabungan Britama, maka nasabah semakin merasa puas. Hal ini berarti bahwa semakin baik kualitas produk tabungan yang diberikan oleh Bank BRI di Sulawesi Selatan, maka nasabah semakin merasa puas terhadap produk Bank BRI di Sulawesi Selatan.

Semakin puas seorang nasabah Bank BRI dalam mengkonsumsi produk tabungan Britama dan simpedes maka dapat dikatakan semakin berkualitas produk tabungan BRI tersebut. Puas atau tidak puasnya seorang nasabah ditentukan oleh kesesuaian antara harapan nasabah dengan persepsi nasabah pada kinerja aktual produk tersebut. Jika kinerja aktual produk lebih besar dari harapan nasabah maka nasabah tersebut akan puas. Hasil penelitian ini juga membuktikan bahwa kajian teoritis dan studi empirik yang menyatakan dan membuktikan adanya hubungan kausalitas yang positif dan signifikan untuk studi dibidang perbankan di Indonesia khususnya pada Bank BRI di Sulawesi Selatan.

Hasil studi ini mendukung studi yang dilakukan Holm (2000), Bei dan Chian (2001), dan Hidayat (2006) bahwa 
kualitas produk berpengaruh langsung terhadap kepuasan konsumen.

Kenyataan dilapangan bahwa masih ada customer service Bank BRI yang belum maksimal memberikan informasi secara detail kepada para nasabah tentang fitur-fitur yang terdapat dalam produk Britama untuk mempermudah nasabah melakukan transaksi keuangan.

Temuan dari penelitian ini adalah kualitas produk mempengaruhi tingkat kepuasan nasabah, hal tersebut dapat dilihat dari nilai $t_{\text {hitung }}$ sebesar 2,488 $>t_{\text {tabel }}$ sebesar 0,67. Oleh karena itu keputusan hipotesis menerima $\mathrm{H} 1$ dan tidak menerima $\mathrm{H} 0$.

\section{SIMPULAN DAN SARAN}

Penelitian ini mencakup analisis kualitatif dan kuantitatif. Hasil wawancara (analisis kualitatif) terhadap responden (nasabah Bank BRI) memberikan jawaban bahwa mereka puas terhadap kualitas produk Bank BRI. Hal tersebut dikarenakan produk Britama memberikan kemudahan bagi nasabah dalam melakukan berbagai macam transaksi. Hal tersebut digambarkan dari kualitas produk yang baik menghasilkan kepuasan nasabah.Sejalan dengan hal tersebut hasil analisis kuantitatif adalah tingkat kualitas produk berpengaruh secara positif dan signifikan terhadap kepuasan nasabah.

Pembahasan dari awal hingga akhir tentang kepuasan nasabah terhadap kualitas produk memiliki pengaruh yang signifikan sebesar $21,8 \%$. Oleh karena itu peneliti memberikan rekomendasi untuk melanjutkan penelitian ini dengan menganalisis variabel lainnya seperti loyalitas nasabah, kualitas layanan, kepercayaan dan relationship marketing atau dengan kajian yang lebih komprehensif.

\section{REFERENSI}

Tjiptono, Fandy. 2004, Pemasaran Jasa, Bayumedia, Malang.
Bei, Lien-T. And Chian, Yu-Chiang, 2001. An Integrated model for the effects of Perceived Product, Perceived Service Quality, and Perceived Price Fairness on Customer Satisfaction and Loyalty, Journal of Consumer Satisfaction, Dissatisfaction and Complaining Behaviour, Vol.14 :pp. 125-141.

Fornell C, MD Johnson, EW. Anderson, Jaesung Cha and B. Everin Bryant. 1996. The American Customer Satisfaction Index: Nature, Purpose and Findings. Journal of Marketing. Vol. 60. Pp. 7-17.

Hidayat, Rachmad. 2009. Pengaruh Kualitas Layanan, Kualitas Produk dan Nilai Nasabah Terhadap Kepuasan dan Loyalitas Nasabah bank Mandiri, Jurnal Manajemen dan kewirausahaan, Vol. 11 No. 1, Maret 2009.

Holm, Mats G. 2000. Service Quality and Product Quality in Housing Refurbishment. The International Journal of Quality and Reliability Management. Vol. 17. Pp. 527-542.

Kotler, Philip. 2009. Marketing Management, alih bahasa oleh Hendra Teguh dan Ronny Rusli. PT Prendalindo. Jakarta.

Oliver, Richard L, 1997. Measurement and Evaluation of Satisfaction Process in Retail Setting. Journal of retailing, Vol. 57. Pp. 25-48.

Sekaran, Uma, 2006, Research Methods For Business, $4^{\text {th }}$ Edition, Kwen Men Yon (Penterjemah) 2006, Salemba Empat, Jakarta.

Suprapto, J. 1997. Pengukuran Tingkat Kepuasan Pelanggan. Jakarta: PT. Rineka Cipta.

Yamit, Zulian. 2004. Manajemen Kualitas : Produk dan Jasa. Yogyakarta 
Jurnal Penelitian IImu Ekonomi WIGA Vol. 7, September 2017, Hal 70 - 76 